\title{
A KONVENCIONÁLIS ÉS AZ ÚJSZERÜ METAFORÁK MEGÉRTÉSI FOLYAMATA A SERDÜLŐ ÉS FIATAL FELNŐTT KOROSZTÁLY ESETÉBEN*
}

\author{
BALÁZS PATRÍCIA ${ }^{1}$ - KEMÉNY FERENC ${ }^{2}$ - IVASKÓ LÍVIA ${ }^{3}$ \\ ${ }^{1}$ Szegedi Tudományegyetem Nyelvtudományi Doktori Iskola; \\ ${ }^{2}$ Budapesti Műszaki és Gazdaságtudományi Egyetem, Kognitív Tudományi Tanszék \\ ${ }^{3}$ SZTE Fejlődéses és Neuropragmatikai Kutatócsoport \\ E-mail: balazs.patricia@gmail.com; fekemeny@cogsci.bme.hu; \\ ivasko@hung.u-szeged.hu \\ Beérkezett: 2013. március 20. - Elfogadva: 2014. június 22.
}

\begin{abstract}
Napjainkban a kognití és kísérleti pszichológián kívül (lásd például TURI és munkatársai, 2010; SWAAB és munkatársai, 2003) a kisérleti pragmatika is kutatási témái között tartja számon a nem szó szerinti jelentések megértésére irányuló kérdéseket (GIORA, 2002, 2007, 2008, 2012; GIBBS 2002). A különösen izgalmas témának tartott metaforák feldolgozási módjait az adatközlök életkorának és kognitív fejlettségének függvényében érdemes vizsgálni (LOUKUSA, LEINONEN és RYDER, 2007/08; SCHNELL, 2007). A serdülő, 15-18 éves korosztály nyelvhasználata és megértési folyamatai viszont jórészt kívül estek a szakirodalmi érdeklödés körén. Cikkünkben a konvencionális és az újszerü, kreatív metafora megértésének folyamatát vizsgáljuk kamasz és fiatal felnött korosztály esetében szó-nemszó lexikális döntési paradigma segítségével. A metaforák három típusú környezetben kerültek bemutatásra: 1. a gyakori jelentést elöfeszito” szövegkörnyezetben, 2. a ritkább jelentést elöfeszitö kontextusban és 3. „lebegtetett" (a gyakori és a ritka jelentést egyaránt elöfeszítö) kontextusban. Célszóként a metafora konvencionális és nem konvencionális (metaforikus) jelentése, illetve álszavak mint kontroll célingerek szerepeltek. Az eredmények azt mutatják, hogy a kamaszok kitüntetett figyelemmel fordulnak az új és ritkán hallott alakzatok felé, azokat gyorsabban értelmezik metaforikus jelentésben, mint a konvencionális metaforákat. A konvencionális formák megértése fokozatos, azaz az életkor elörehaladtával nö a megértés.

Kulcsszavak: kísérleti pragmatika, serdülő korosztály, konvencionális és újszerü metafora, lexikális döntés, metaforikus jelentés

* Köszönettel tartozunk a kísérletsorozat felvételében nyújtott segítségért Andrási Krisztinának (Bibó István Gimnázium, Kiskunhalas), Idrisz Ágnesnek (SZTE, Nyelvtudományi Doktori Iskola, Kossuth Lajos Gimnázium, Budapest) és Marjanucz Lillának (Tömörkény István Gimnázium és Művészeti Szakközépiskola, Szeged).
\end{abstract}




\section{BEVEZETÉS}

A pragmatikai szakirodalomban nagy hagyománya van a nem szó szerinti jelentések megértésére irányuló nyelvfilozófiai vizsgálódásoknak (SEARLE, 1979; GRICE, 1997a, 1997b), a kognitív nézőpontot alapul vevő (SPERBER és WILSON, 1986/95) kísérletes kutatások pedig az elmúlt években léptek előtérbe (GIORA, 1997, 2002, 2007, 2008, 2012; GIBBS, 2002; RuBIO, 2007, 2008). Más kutatások az elsajátításra koncentrálva foglalkoznak a nem szó szerinti nyelvhasználattal, és ma már egyre több információnk van a gyermeki, leginkább az óvodás korosztály kognitív folyamatainak működéséről (lásd például SCHNELL, 2007; GERőCS és PINTÉR, 2013), viszont marginális szerepet kapott a serdülő, 15-18 éves kamaszok jel- és nyelvhasználatának és a nem szó szerinti jelentésekre vonatkozó interpretálási stratégiáinak vizsgálata. Egyes magyar nyelvű kutatások a kamaszok nyelvhasználatát produkciós szempontból, formai sajátosságait nézve vizsgálják, melyek közül kiemelik gyorsuló beszédsebességüket, „artikulációs nehézségeiket, hangképzési rendellenességeiket, a hangsúlyozási problémákat vagy a kifejezésbeli nehézségeket” (LACZKó, 2008; a témában lásd még LACzKÓ, 2009, 2011). A vizsgálatok szerint mindez szótalálási problémákkal, szójelentési nehézségekkel és szleng nyelvhasználattal párosul, így a szakirodalom a kamasz korosztály e sajátosságait összességében negatív jelenségként és káros nyelvhasználatként értékeli. Ám ezek a kutatások főként a produkció oldaláról vizsgálták a kamaszok nyelvhasználatát, a nem szó szerinti jelentések interpretációjáról kevés információ áll egyelőre rendelkezésünkre. Érdeklődésünk középpontjában annak a kérdésnek a megválaszolása állt, hogy mi módon képesek feldolgozni a serdülők a szó szerinti és a nem szó szerinti jelentéseket.

\section{A KAMASZ NYELVHASZNÁLAT KOGNITÍV PSZICHOLÓGIAI ALAPJAI}

Korábbi, tipikus (SCHNELL, 2007) és atipikus fejlődést vizsgáló kutatásokból (BARON-CoHEN, TAGer-FlusberG és CoHEN, 1993, 2007; HAPpé, 1993; LAVAL és BERnicot, 2002; Bernicot, LAVAl és CHAMinaud, 2007; SCHNEll, 2007; GyŐRI, GY. STEFANIK, KANIZSAI és BALÁZS, 2002; GYŐRI, 2006) és saját vizsgálataink alapján tudjuk (IVASKó, 2004; LENGYEL, BALÁZS és IVASKÓ, 2011), hogy 4 éves kor körül forradalmi változás áll be a nyelvhasználatban. Ekkorra a tudatelméletnek nevezett komplex kognitív képesség elég fejlett lesz ahhoz, hogy képes legyen hozzájárulni a mások céljainak és szándékainak átlátásával, a mások nézőpontjának figyelembevételével a különböző nyelvi alakzatok megértéséhez. A pragmatika és a tudatelmélet közti szoros kapcsolatokat a fejlődésben először BARON-COHEN, LESLIE és FRITH (1985) mutattak ki autista gyermekekkel végzett vizsgálataikban. Magyar nyelven Győri Miklós és munkatársai (GYŐRI, GY. STEFANIK, KANIZSAINAGY és BALÁZS, 2002; összefoglalást lásd LUKÁCS és PLÉH, 2003) mutattak rá autista gyermekekkel végzett vizsgálataik során, hogy a tudatelméletnek nemcsak a „másodlagos reprezentációs feladatokban van központi szerepe, mint például a téves vélekedés feladatban, hanem magának a nyelvnek a feldolgozásában is" (LUKÁcs és PLÉH, 
2003, 552). Vagyis a tudatelmélet nemcsak a már meglévő reprezentációkat kezelő metareprezentációs feladatokat lát el, hanem elemibbeket is (LuKÁcs és PLÉH, 2003). A tudatelmélet két komponensből áll: a társas-perceptuálisból, amely alapján döntünk mások arckifejezésének és gesztusainak megítélésében, és a társaskognitívból, mely a hagyományos értelemben vett tudatelméletet jelenti (LUKÁCS és PLÉH, 2003). A tudatelmélet társas-perceptuális aspektusa, köztük az egyén másoktól való megkülönböztetése, illetve az emóciók észlelése már csecsemőkorban elkezdődik (CSIBRA és GERGELY, 2007), de Tomasello szerint (TOMASELlo, 2002; CALl és TOMASELLO, 2008) a szándéktulajdonítási képesség kialakulása, amely segítségével másokat a mieinktől eltérő szándékvezérelt ágenseknek tekintünk, körülbelül 4 éves korra tehető. Ez teszi lehetővé, hogy „a szándékra való következtetéssel ki tudjuk következtetni a szándékolt, azaz a nem szó szerinti jelentést" (SCHNELL, 2008, 240).

Schnell kutatásai szerint az idiomatikus interpretáció kulcsfontosságú mozzanata a tudatelméleti képesség, amellyel a szándékolt jelentést interpretálni tudjuk a társas és szituációs kontextus figyelembevételével (SCHNELL, 2007). Schnell óvódások metafora-, illetve idiómaértelmezését vizsgáló eljárása kimutatta, hogy a tudatelmélettel rendelkező gyermekek csoportja szignifikánsan jobban teljesített a szándékolt jelentés megfejtésében, mint a tudatelmélettel nem rendelkező társaik (SCHNELL, 2007).

Az elmúlt években egyre több olyan vizsgálat látott napvilágot (BLAKEMORE, Den Ouden, Choudhury és Frith, 2007; Burnett, Thompson, Bird és BLAKEMORE, 2011; BLAKEMORE, 2011, 2012a, 2012b), amelyek szerint a tudatelmélet fejlődése nem áll meg 4-5 éves korban, hanem a gyermek- és a serdülőkoron át egészen a fiatal felnőttkorig tart. Ezekben a kutatásokban a kamaszkor kezdetének a pubertást, végének pedig - a nyugati kultúra hagyományainak megfelelően - a fiatal felnőttek munkába állását tekintik. A kamaszok jellemzően a Piaget által megjelölt kognitív fejlődési (PIAGET, 1958) és személyiségfejlődési szakaszokon mennek át (ERIKSON, 1968), amelyek során nemcsak hatékonyabb mentális műveletek elvégzésére lesznek képesek, hanem kialakítják saját identitásukat és meghatározzák magukat a másokkal való együttműködési képesség fényében. A serdülők nagymértékben szociálisak, komplex és hierarchikus kapcsolatokat képesek kialakítani kortársaikkal. Ilyenkor a serdülö önmaga és társai megértésére és másoktól való elkülönítésére sajátos nyelvhasználatot hoz létre, valamint fogékonyabb lesz a nyelvhasználati különlegességek produkciójára és megértésére. Az ifjúsági, kamasz nyelvhasználat a fiatalokra jellemző, felnőttekétől eltérő szókészlet és nyelvhasználat, melynek legfontosabb feladata, hogy kifejezze az egy közösséghez, a kortárscsoporthoz tartozást, valamint speciális nyelvhasználatuk saját identitásuk megerősítését szolgálja. Az identitás kialakításának vágya miatt elhatárolódnak a felnőttek világától, és nem törekednek a megfelelésre, sőt provokatív kommunikációjukkal és reakcióikkal szívesen döbbentik meg a közönséget. Csoporthoz való tartozás iránti igényük erős, és az egyén, illetve a közösség számára különleges jelentésủ, általában érzelmi töltésủ szavak csak az adott csoport számára értelmezhetők (ERIKSON, 1968). Erikson szerint az identitásképzés a serdülőkorban azért különleges jelentőségű, mert ekkor a kamaszok vágyainak és 
vélekedéseinek össze kell hangolódni a felnőtt normákkal, de ez az identitáskialakítással járó válság belső konfliktust szül az egyénben.

A serdülőkor gondolkodási műveletei is fejlődésen mennek keresztül: nagy szerepet kap a lehetőségekről való gondolkodás és előregondolkodás, azaz nemcsak a közvetlenül megfigyelhetőn való gondolkodás lesz a jellemző, hanem az alternatív lehetőségeken is (KEATING, 1980). Továbbá jelentős szerepet tölt be a metagondolkodás, a gondolkodási folyamatokról való gondolkodás, tehát a módszeres problémamegoldáson túl jobban figyelembe tudják venni más nézőpontjait. Piaget ezt nevezte a formális műveletek szakaszának, amely szakaszban a kamasz egy feladat megoldásakor tekintetbe veszi az összes lehetséges kombinációt (PIAGET, 1958).

A kamaszok szívesen használják az elvont verbális fogalmakat: ez megmutatkozik abban, ahogy a serdülők ismeretlen szavak jelentését fejtik meg, és abban, ahogy ismert szavak kapcsolataiból következtetéseket vonnak le. WERNER és KAPLAN (1952) kísérletükben olyan mondatok sorozatát állították össze, amelyek mindegyike tartalmazott egy értelmetlen szót, amelynek jelentését a kontextusból kellett kitalálni. Eredményeik szerint 11-12 évesek képesek voltak arra, hogy egy megfelelő definíciót találjanak ki, azaz összevetették az egyes mondatokhoz tartozó lehetséges jelentéseket, és végül megtalálták azt az egyet, amely mindegyikhez illett. Hogy a szójelentésnek milyen új struktúrái alakulnak ki a serdülőkorban, arra jó példa saját, spontán beszélgetést imitáló vizsgálatunk (LENGYEL, BALÁzs és IVASKÓ, 2011), mely azt mutatta ki, hogy a nem szó szerinti jelentések megértése 6 és 13 éves kor között fokozati kérdés. Eredményeink szerint konvencionális metaforák nem szó szerinti jelentésének megértési aránya az életkor előrehaladtával növekedett. A kiskamaszok a számukra ismeretlen, kreatív, újszerű metaforákat (dobbant, tacskó) is minden alkalommal kooperatívan, a lehető legrelevánsabban, a kontextusnak és a szituációnak megfelelően próbálták értelmezni, ám az esetek nagy részében azonban nem a beszélő szándékainak megfelelően interpretálták a jelentését. Az így bevezetett 'nem szándékolt, nem szó szerinti jelentés' fogalma azt a jelentést takarta, amikor nem szó szerinti értelemben ugyan, de nem a beszélő szándékainak megfelelően értelmezték a metaforát. Eredményeink szerint nemcsak 4 éves kor körül figyelhető meg a tudatelmélet ugrásszerủ fejlődése, hanem 8-9 éves kor körül is. Az 1. és 2. ábra egy konvencionális és egy újszerű metafora megértésének eredményeit mutatja be a 6-13 éves korosztálynál (LENGYEL, BALÁZS és IVASKÓ, 2011).

E szerint 6-7 éves kortól kezdve a kontextus figyelembevételével próbálják kikövetkeztetni a megnyilatkozás értelmét, ám nem rendelkeznek stabil szándéktulajdonító és mentalizációs képességgel (lásd még óvodás korú gyermekek tudatelméleti fejlettsége és a nem szó szerinti alakzatok megértése közti összefüggés: SCHNELL, 2007). Emiatt nem jutnak el minden esetben a szándékolt jelentés megértéséhez még 8-9 évesen sem. 


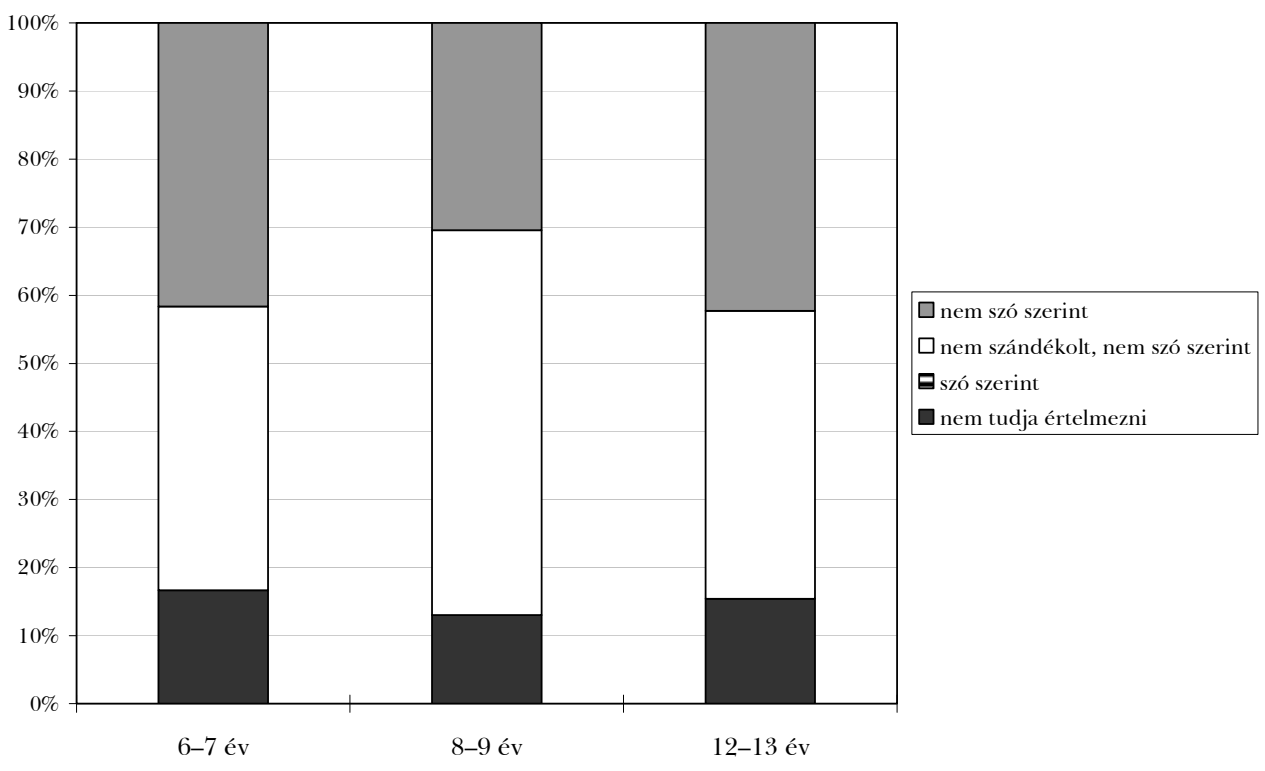

1. ábra. A konvencionális metafora megértésének változásai az életkor szerint

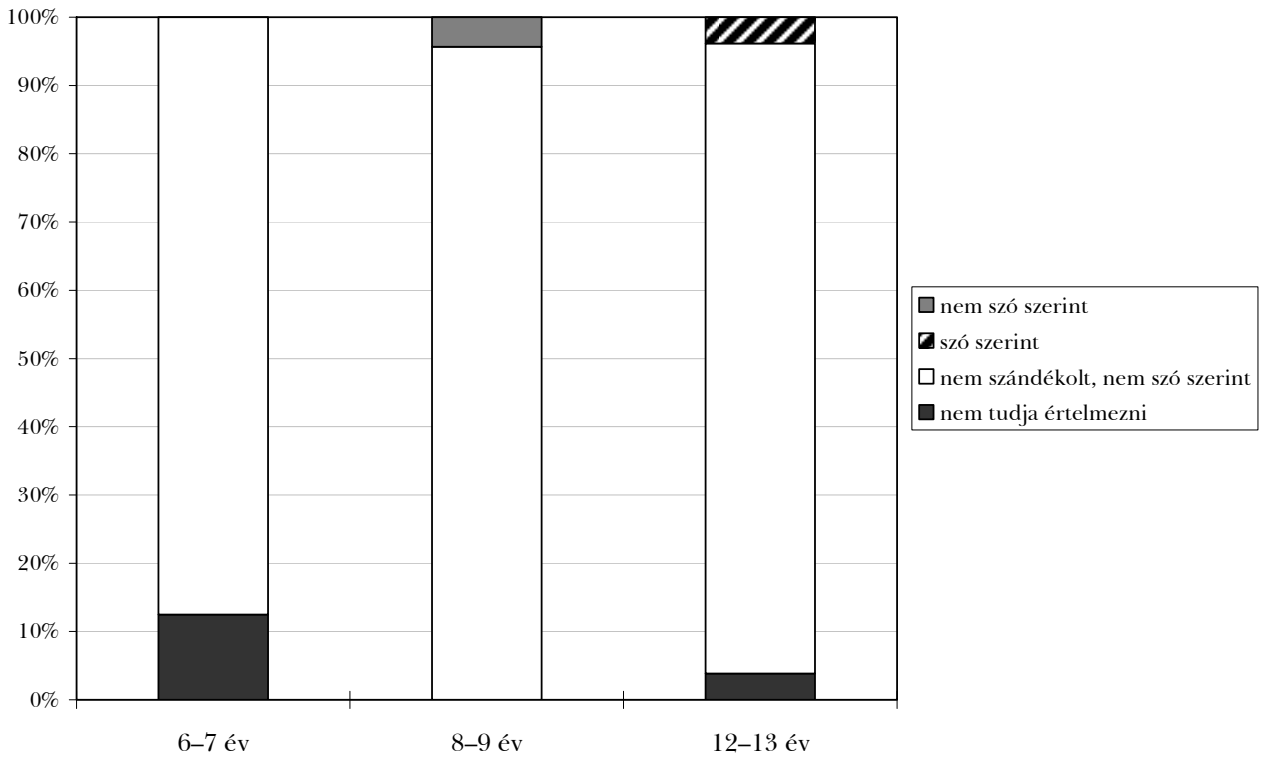

2. ábra. Az újszerủ metafora értelmezése a korcsoportok függvényében 


\section{AZ ÚJSZERÜ ÉS A KONVENCIONÁLIS METAFORÁK MEGÉRTÉSÉHEZ HASZNÁLT KOGNITÍV PRAGMATIKAI ELMÉLETI KERET}

A pragmatikaelméletek közül a relevanciaelméletet (SPERBER és WILSON, 1986/95) képes leginkább számot adni a megértés sikerességéről vagy sikertelenségéről, legyen az szó szerinti vagy nem szó szerinti jelentés. A relevanciaelmélet szerint a nem szó szerinti jelentések interpretálása semmiben nem különbözik a szó szerinti jelentések megértésétől (SPERBER és WILSON, 2013), hiszen mindkettőt az optimális relevancia elve irányítja. A relevancia lehet egy megnyilatkozás, egy külső stimulus vagy belső reprezentáció (gondolatok, következtetések, konklúzió) tulajdonsága. Mivel a kontextust nem adottnak, hanem a megnyilatkozás során, a kommunikátor és a hallgató által együttesen felépített konstruktumnak kell tekinteni, a kontextushoz viszonyított relevancia megadása nem lehetséges. Ezért az individuumok számára értelmezett relevanciát kell alapul venni. Egy input akkor releváns az egyén számára, ha az összekötve különböző kontextuális feltevésekkel pozitív kognitív hatást eredményez. Kognitív hatás pedig háromféle lehet: igaz kontextuális implikáció, meglévő feltevés erősítése vagy meglévő feltevés elvetése. A metafora szempontjából a legfontosabb kognitív hatás a kontextuális implikáció, amely a kontextusból és az inputból együttesen következtethető ki deduktív következtetések révén. Az input relevanciája akkor a legnagyobb, ha a megnyilatkozás minél nagyobb kognitív hatással jár, minél kevesebb mentális erőfeszítés révén. Így meg lehet fogalmazni a két relevancia elvet (SPERBER és WILSON, 1986/95, 260).

\section{A) Kognitív relevancia elve}

A humán kogníció mindig a relevancia maximalizálására törekszik, mivel a perceptuális, a következtetési rendszerünk és a memóriánk automatikusan a potenciálisan releváns stimulusok között válogat.

\section{B) Kommunikatív relevancia elve}

Minden kommunikációs aktus saját optimális relevancia elvárásával születik (a kommunikátor a képességeinek és preferenciáinak megfelelően a legrelevánsabbat választja $\mathrm{ki}$ ).

A relevanciaelmélet heurisztikus, on-line, ún. nem-demonstratív következtetési modellt vázol, amely a beszélő és a hallgató kölcsönösen egyezkedő és a kontextust közösen strukturáló tevékenységére alapoz. Azt állítja, hogy a beszélőnek a preferenciáihoz és képességeihez mérten a lehető legrelevánsabb stimulust kell előállítania, a hallgatónak pedig a megnyilatkozás interpretációjakor azt az utat kell követnie, amely a lehető legkevesebb erőfeszítéssel jár, és akkor kell leállítania az interpretációt, ha igaz kontextuális implikációkhoz jut, tehát teljesül relevanciaelvárása. Az ehhez szükséges pragmatikai folyamatok nem szekvenciálisan, hanem egymással párhuzamosan futnak, hipotéziseket gyártva a kontextusról, az explicit tartalomról és kognitív hatásokról. Ehhez azonban a beszélő „fogódzókat” nyújt: egyrészt informatív szándéka segítségével informálja a hallgatót világ egy tényállá- 
sáról, másrészt kommunikatív szándéka megmutatásával (osztenzió) informálja a hallgatót az informatív szándékáról is (informatív-kommunikatív szándék: SPERBER és WILSON 1986/95). A hallgató célja a beszélői jelentés (speaker's meaning) megtalálása, amely kielégíti a relevancia elvárását.

\section{Konvencionális és újszerü metafora a relevanciaelméletben}

SPERBER és WiLSON (1986/95) szerint a megnyilatkozás és a beszélő gondolatai közti kapcsolat mindig egy interpretatív hasonlóság a megnyilatkozás és a gondolat propozíciós formája között. A megnyilatkozás értelmezése során a hallgató feltevéseket gyárt a beszélő informatív szándékáról, de a megnyilatkozás propozíciója nem mindig azonos a beszélő gondolatának propozíciójával, és nem minden kontextuális implikáció köthető össze az eredeti gondolattal. Ha mégis azonos a gondolat az általa generált feltevésekkel, akkor a megnyilatkozást szó szerintinek kell tekinteni (SPERBER és WILSON, 1986/95). A szerzőpáros a szó szerintiséggel nem is foglalkozik többet, mert szerintük sokszor a legrelevánsabb implikáció éppen az, amelyik nem azonos az eredeti gondolattal, mivel ennek feldolgozása kerül a kisebb erőfeszítésbe. Sokszor nem is szó szerint beszélünk, hanem „bővítjük” (broadening) mondanivalónkat. Ezt nevezik „loose use”-nak is, vagyis laza vagy közelitő nyelvhasználatnak. Laza nyelvhasználatról beszélünk például akkor, amikor a „buldózer” kifejezést használjuk olyan személyre, aki erőteljes személyiség (SPERBER és WiLSON, 1986/95). Ilyenkor a metafora tágabb értelmezése történik, és absztrakt szintre emeljük a jelentést. A relevanciaelméletnek megfelelően a hallgató az értelmezés során tisztában van vele, hogy a kommunikátor megnyilatkozása és gondolata sosem lehet teljesen azonos, de feltételezi, hogy a kommunikátor a lehető legrelevánsabb információt nyújtotta számára, azaz a kommunikatív relevancia elve alapján az optimálisan releváns információt közölte. Ennek értelmében, ha a hallgató nem szó szerinti megnyilatkozással találkozik, joggal feltételezheti, hogy releváns a mondanivaló, de bizonyos erőfeszítéseket kell tennie a jelentés megértéséhez.

Az elmélet az erős és gyenge implikáció fogalmának bevezetésével megkülönbözteti a konvencionális és az újszerủ metaforákat. Konvencionális metaforák azok a metaforák, amelyek erős implikáció segítségével jönnek létre, mikor a kommunikátor osztenzív viselkedésével erőteljesen jelzi, hogy a megnyilatkozást a hallgatónak az általa közölni kívánt módon kell értelmezni. Nézzük a következő példát.

(1) Az apa mondja rosszallóan a fiának: A szobád egy disznóól. ${ }^{1}$

A hallgató ezt a metaforát hallva a disznóól lexikai fogalmához tartozó enciklopédikus jegyeket hívja elő, amelyek közt könnyedén megtalálhatja azt a sztereotip tulajdonságot, hogy a disznóólak piszkosak és büdösek. Ez a megnyilatkozás rendelkezik egy erős implikációval, miszerint 'a szobád piszkos'. Ez a fajta erős implikáció

1 Sperber és Wilson, 1995, 236. 
azonban adódik a gyakori használatból is, így természetes, hogy a jelentés megfejtése a lehető legkevesebb energiát emészti fel a hallgató részéről. Az relevanciaelmélet konvencionális metaforákról alkotott nézete hasonló Glucksberg kettős referencia elképzeléséhez (GLUCKSBERG, 2003). E szerint a metafora hordozója (vehicle) kettős referenciával rendelkezik: az aktuális szó szerinti jelentésével és egy magasabb rendű, metaforikus kategóriával.

Ezzel szemben egy kreatív (újszerủ) metafora megértése nagyobb erőfeszítést követel:

(2) Mari mondja Tamásnak Róbertröl, akivel mindketten együtt dolgoznak. - Róbert egy bulldózer. ${ }^{2}$

Ebben az esetben a kommunikátor gyenge implikációkat, következtetéseket hoz létre, amelyek közül minimum egyet meg kell találnia a hallgatónak, hogy megértse a metaforát. Éppen ezért megértésük több kognitív energiát emészt fel, de a kommunikátor részéről ezt éri meg leginkább kommunikálni, a hallgató pedig a relevanciát és a partner szándékait együtt keresve értelmezi a megnyilatkozást. Láthatjuk, hogy a metafora két alkotóelemének, a topicnak és a hordozónak nincsenek közös tulajdonságai. CARSTON $(2002,2010)$ szerint ekkor a két rész enciklopédikus ismeretei és az aktuális kontextus alapján egy magasabb rendủ ad hoc fogalmat generálunk, amely egyszerre tartalmazza a hordozó pszichológiai (absztrakt) és a fizikai (alapjelentés) jelentésének tulajdonságait is. A relevanciaelmélet összességében nem különbözteti meg a szó szerinti nyelvhasználat és a nem szó szerinti nyelvhasználat feldolgozását, hanem egy kontinuum két végére helyezi őket. Ezzel azt állítják a szerzők, hogy nem húzható éles határ a szó szerinti és nem szó szerinti jelentések közé, hanem átjárható kategóriáknak tekintik őket (SCHNELL, 2012, 2013), mely átjárhatóság többek közt a konvencionalizáltság mértékén is múlik. A relevanciaelmélet ugyanakkor felhívja a figyelmet, hogy egyes jelentések megértése kevesebb erőfeszítést igényel, míg más jelentéseké többet, illetve hangsúlyozza, hogy a releváns jelentés keresése anélkül történik meg, hogy a konvencionális jelentést feltétlenül az elemzés részévé tennénk. Ez az álítás összhangban van GIBBS és COLSTON (2012) munkájával, amely szerint a 'szó szerinti jelentés' terminus számos olyan egyéni és kontextuális faktortól függ, amely gyakran szituációról szituációra változik, így nem is jelenthető ki, hogy a metaforikus jelentés megértéséhez feltétlenül a teljes szó szerinti jelentést fel kell dolgozni.

\section{A METAFORÁK MEGÉRTÉSÉNEK ONLINE VIZSGÁLATA}

A vizsgálat a 15-18 éves serdülő korosztály konvencionális és az újszerủ metafora megértési stratégiáira koncentrált. Eredményeiket egy fiatal felnőtt csoporttal (2227 év) hasonlítottuk össze. Célunk az volt, hogy megvizsgáljuk a két korosztály

2 Sperber és Wilson, 1995, 236; Carston, 2002. 
metaforafeldolgozási sebességét, mivel - hipotéziseink szerint - ha megnövekedett reakcióidőt találunk, akkor ez egyik vagy másik jelentés feldolgozására irányuló extra műveleti erőfeszítésre utal.

\section{HIPOTÉZISEK}

1. Szakirodalom alapján feltételezzük, hogy a fiatal felnőtt adatközlők a konvencionális metaforákat gyakoribb használatuknál fogva gyorsabban képesek feldolgozni, mint az újszerủ metaforákat (GIORA, 1997, 2012). A felnőttek inkább a száliens, gyakori és prototipikus jelentést preferálják, és kevesebb energiát fordítanak az újszerü alakok megértésére.

2. A konvencionális metaforáknál a száliens, domináns (= metaforikus, nem szó szerinti) jelentés hívódik elő a felnőtt korosztálynál, tekintet nélkül a kontextusra. A verifikációs időt nem befolyásolják a különböző kontextustípusok, tehát minden kontextusban ugyanolyan gyors lesz a döntés.

3. Újszerű metaforákat lassabban értik meg a felnőtt adatközlők az egyes kontextusokban, mert a metaforikus jelentés megtalálásában a kontextussal való egyeztetés és nagyobb erőfeszítés szükséges. A kamaszok az újszerű metaforák metaforikus jelentésének megtalálásában jobban teljesítenek, míg a konvencionális metafora megértésében kevésbé jól teljesítenek, annak ellenére, hogy azok gyakoriak a hétköznapi nyelvhasználatban.

4. Vizsgálatunkban álszavakat használtunk kontrollfeladatként és referenciaként. Az álszavakhoz kapcsolódó döntési időt referenciaidőnek tekintve azt mondhatjuk, hogy a szituációhoz járuló nem létező szavakról való döntés pontatlanabb lesz, és reakcióideje lassabb, mint a másik két jelentésről való döntés, mert nemcsak szemantikájukról kell dönteni (jelentése illeszthető-e a szöveghez), hanem fonológiai és morfológiai döntést is kell hozni róla (magyar morfológiai szabályoknak megfelelő-e). Valamint az álszavak esetében nincs szemantikai előfeszítés, ezért is lehetséges, hogy a róluk szóló döntés lassabb és pontatlanabb lesz. Azt jósoljuk tehát, hogy az álszavakhoz képest a száliens jelentésről szóló döntés kifejezetten gyorsabb lesz, mert aktivációjuk automatikus, sem a kontextustól, sem fonotaktikai és morfológiai szabályoktól nem függ.

\section{MÓDSZERTAN}

\section{Eszközök}

A lexikai döntéses előfeszítési feladat során a kísérleti személyek először egy rövid, 1-2 mondatos szöveget olvastak, amelynek az utolsóelőtti vagy az utolsó szava metaforikus értelmủ volt. A szöveg elolvasása után a kísérleti személy megnyomta a szóköz gombot. Ekkor megjelent a célinger, amelyről el kellett döntenie, hogy szó vagy nem szó. A metaforák lehettek konvencionálisak vagy újszerűek (ME), illetve a kontextus előfeszíthette a gyakori jelentést, a ritka jelentést vagy mindket- 
tőt („lebegtetett kontextus”). A célingerek lehettek a metaforikus értelemhez kapcsolódóak, a szó szerinti jelentéshez kapcsolódóak vagy álszavak. Legfontosabb információnak a konvencionális és nem konvencionális jelentés közötti eltérő reakcióidőt tekintettük, mivel egyik vagy másik megnövekedett reakcióideje többlet erőfeszítésre utal. A kísérleti személyek egy ülés alkalmával 118 rövid szöveget olvastak, de a tényleges vizsgálat előtt 8 darab próbafeladatot végeztek el, amelyek mentesek voltak a metaforáktól, a próbafeladatok csak a vizsgálat során használt billentyűkombinációk begyakorolását szolgálták. A vizsgálati anyag előtesztjeként egy korábbi vizsgálatunk (LENGYEL, BALÁzs és IVASKÓ, 2011) szolgált. Ennek segítségével kizártuk, hogy a tesztanyagba olyan inger kerüljön, amelyet nem értenek, vagy félreértenek. A vizsgálati eljárás során az egyes részeket randomizáltuk, vagyis a szöveg-célszó kombinációk előre meghatározottak voltak, de a sorrendjük nem.

A kísérlet során a célingereket három nagy csoportra bontottuk: 1 . álszó, amely a magyar hangrendnek és morfológiai szabályoknak megfelelt ugyan, de nem létező magyar szó volt (RACSMÁNY, LuKÁCS, NÉMETH és PlÉH, 2005); 2. target, amely a metafora nem szó szerinti jelentéséhez kapcsolódik, és 3. célszó, amely a metafora szó szerinti jelentéséhez kapcsolódik. A célingerek kiválasztásakor gondosan ügyeltünk arra, hogy az egyes jelentésekhez tartozó célingerek csoportjai között ne legyen eltérés a szavak gyakorisága és szótagszáma között, valamint az álszavak is olyan szótagszámúak legyenek, mint a másik két célszó.

GIORA (1997, 2002, 2008) korábbi munkái alapján feltételeztük, hogy a metaforák jelentéseinek gyakorisága különböző: egyes metaforikus jelentések fixen kódolva vannak a mentális lexikonban (száliens vagy vezérjelentések) míg mások kevésbé gyakoriak és kevésbé prototipikusak (kevésbé kiemelkedő vezérjelentések). Például a kitálal konvencionális metafora esetében a nem szó szerinti (metaforikus) jelentés a gyakoribb (NEMESI, 2009), így nem szó szerinti vezérjelentésű lesz. Ezzel szemben a tacskó újszerủ metafora esetében - éppen újdonsága és kreatív volta miatt - szó szerinti vezérjelentéssel számolhatunk.

A vizsgálati anyagban használt metaforák két csoportra bonthatók: konvencionális és újszerủ metaforákra. Konvencionális metaforáknak olyan alakzatokat minősítettünk, amelyeket empirikus vizsgálatok alapján már gyakorinak, megszo-

1. táblázat. A konvencionális és az újszerủ metaforák csoportosítása

\begin{tabular}{|c|l|l|}
\hline Frekventáltság/vezérjelentés & \multicolumn{1}{|c|}{ Ritka } & \multicolumn{1}{|c|}{ Gyakori } \\
\hline \multirow{3}{*}{ Nem szó szerinti vezérjelentés } & ujjbotlás $^{3}$ & kitálal \\
\cline { 2 - 3 } & banyatank & sütnivaló \\
\cline { 2 - 3 } & dobbant & cicázik \\
\hline \multirow{3}{*}{ Szó szerinti vezérjelentés } & ujjtörő & sláger \\
\cline { 2 - 3 } & tacskó & lefegyverez \\
\cline { 2 - 3 } & csücsök & vetít \\
\hline
\end{tabular}

3 A külön nem idézett példák vagy élőnyelvi példák, vagy saját intuíció lapján létrehozott metaforák. 
kottnak, a beszélőközösség által gyakran használtnak és elfogadottnak ítéltek (lásd NEMESI, 2009 felsorolását). A konvencionális metaforákat ME1 rövidítéssel, az újszerű metaforákat ME2 rövidítéssel jelöltük. Újszerủ metaforák pedig a vizsgálatot tervező nyelvészek által, intuíció alapján „kreált” alakzatok, vagy egy-egy informális társalgás során elhangzott alkalmi alakzatok, azaz olyanok, amelyekkel eddig biztosan nem találkoztak sem a kamasz nyelvhasználók, sem a felnőtt adatközlők. A kísérlet igyekezett nem költői, hanem a hétköznapi társalgásban előforduló alakzatokhoz hasonló formákat használni. A vizsgálatban használt metaforákat az 1. táblázatban közöljük.

Lássunk egy-egy példát a metaforák típusaira, a kontextusra és a hozzájuk kapcsolódó jelentésekre.

\section{Konvencionális metafora (ME1)}

\section{Lefegyverez}

Nem szó szerinti jelentést támogató kontextus:

Olyan világban élünk, hogy a bizalom és az öszinteség, nemre, korra való tekintet nélkül mindenkit lefegyverez. ${ }^{4}$

Szó szerinti jelentést támogató kontextus:

Olyan világban élünk, hogy a katonaság és a parancsnok nemre, korra való tekintet nélkül mindenkit lefegyverez.

Lebegtetett kontextus:

Olyan világban élünk, hogy néhány dolog nemre, korra való tekintet nélkül mindenkit lefegyverez.

A kontextushoz kapcsolódó szavak a következők lehettek:

1. álszó: hápamarogány

2. nem szó szerinti jelentés: elbűvöl

3. szó szerinti jelentés: fegyverletétel

\section{Újszerű metafora (ME2)}

\section{Tacskó}

Nem szó szerinti jelentést támogató kontextus:

Egyszer egy fiú és egy lány úgy összevesztek, hogy a fiú még a lány haját is meghúzgálta. A lány erre azt mondta rá, hogy: De egy tacskó vagy!

4 NeMesi, 2009. 
Szó szerinti jelentést támogató kontextus:

Egyszer egy fiú és egy lány úgy összevesztek, hogy a fiú még a lány karját is megharapta. A lány erre azt mondta rá, hogy: De egy tacskó vagy!

lebegtetett kontextus:

Egyszer egy fiú és egy lány összevesztek. A lány erre azt mondta rá, hogy: De egy tacskó vagy!

A kontextushoz kapcsolódó szavak a következők lehettek:

1 álszó: vikula

2. nem szó szerinti jelentés: éretlen

3. szó szerinti jelentés: kiskutya

A kísérlet során háromféle szövegkontextust alkalmaztunk: 1. a gyakori kontextus, amely a gyakori jelentést feszíti elő; 2 . a ritka kontextus, amely a ritkább jelentést facilitálja, illetve 3. a lebegtetett kontextus (IVASKÓ, 2009), mely egyaránt támogatja mindkét jelentést, tehát az adatközlők fele-fele arányban választhatják szó szerinti és a nem szó szerinti értelmezést is. Így a szövegkörnyezet erős hezitációt eredményez, a hallgató előzetes ismereteitől, az aktuális szituációtól, egyéni döntésétől függ, melyik értelmezést fogadja el.

\section{Kisérleti eljárás}

A vizsgálatban E-Prime 2.0 (Psychology Software Tools, In, Pittsburgh, PA) kísérleti programot alkalmaztunk. Mivel a vizsgálat névtelenül zajlott, a kísérletben részt vevők a program indításakor először egy, a kísérletvezető által előre megadott sorszámot kaptak, majd a 'nem' és 'születési dátum' megadását kértük. A kísérletvezető a vizsgálat megkezdése előtt szóban is összefoglalta a rájuk váró feladatot, elmondta az instrukciókat, és hangsúlyozta, hogy a cél az, hogy a lehető leggyorsabb döntést hozzanak a személyek arról, hogy a szöveg után megjelenő szó létező magyar szó-e vagy nem. Ezután a képernyő közepén az instrukciót láthatták, majd a valós kísérlet a nyolc próbafeladat után következett. A kísérleti személyek a következő instrukciót láthatták: „Olvasd el a történetet. Ha elolvastad, nyomd meg az Enter-t. Ezután a képernyön egy szót fogsz látni. Döntsd el, hogy van-e ilyen magyar szó, vagy sem. Ha létezik, nyomd meg az A billentyüt! Ha NEM létezik, nyomd meg az L billentyüt! A feladat gombnyomásra indul!"

A képernyő felső részén, fehér háttéren megjelent a szöveg, amely a szóköz billentyủ megnyomásáig látható maradt. A szóköz lenyomása után 250 milliszekundum késleltetés után megjelent a célinger, amelyről el kellett dönteni, hogy kapcsolódik vagy sem a szituációhoz. A célinger a válaszadásig volt látható, majd egy 500 ms-os késleltetés után megjelent a következő item. Összesen 145 item volt, az 50. és 100. item után egy önütemezett szünetet tarthattak a résztvevők. 


\section{Résztvevők}

A kísérletben serdülő és fiatal felnőtt korosztály vett részt. Az első kísérletben 20 magyar anyanyelvű, 15 és 17 év közötti (átlag $=16,09$, szórás $=0,68$ ) középiskolás diák szerepelt (15 nő, 5 férfi). A személyek önkéntes alapon vállalták a kísérletben való részvételt, mivel az adatközlők 18 éven aluli kiskorú személyek voltak, ezért az adatfelvétel előtt a szülők részletes tájékoztatást kaptak a vizsgálatra vonatkozóan, és a vizsgálatot a szülői beleegyező nyilatkozat aláíásával engedélyezték. A második kísérletben a feladatokat megismételtük a fiatal felnőtt korosztálylyal is. Ebben összesen 23 fö egyetemista (10 nő, 13 férfi, átlagéletkor $=24,76$, szórás $=3,13$ ) adatközlő vett részt.

\section{A kamasz korosztály eredményei}

A pontossági és a reakcióidő mérés adatainak elemzését három szempontú, 2 (metafora típusa: konvencionális, újszerű) $\times 3$ (kontextus: gyakori, lebegtetett, ritka) $\times 3$ (jelentés: nem szó szerinti, szó szerinti, nem kapcsolódó) összetartozó mintás ANOVA segítségével elemeztük.

Illeszkedés szempontjából (a kontextus és a jelentés egymáshoz való illeszkedésének mértéke) csak a legfontosabb hatásokat emeljük ki. A metafora típusára vonatkozóan tendenciaszerủ hatást figyeltünk meg $(\mathrm{F}(1,19)=3,084 p<0,095)$, ami arra utal, hogy a serdülő korosztály kontextushoz illeszkedőbbnek találja az újszerủ metaforákat, mint a konvencionálisakat. Az ME $\times$ jelentés közti szignifikáns interakció $(\mathrm{F}(1,19)=10,341, p<0,005)$ azt jelzi, hogy a konvencionális metaforához illő nem szó szerinti jelentést kevésbé találják illeszkedőnek $(95,6 \%)$, mint az újszerű metaforához a nem szó szerinti jelentést $(99,2 \%)$. A szó szerinti jelentés illesztése a metafora két fajtájnál nem különbözött $(99,2 \%$ és 98,1\%) (3. ábra).

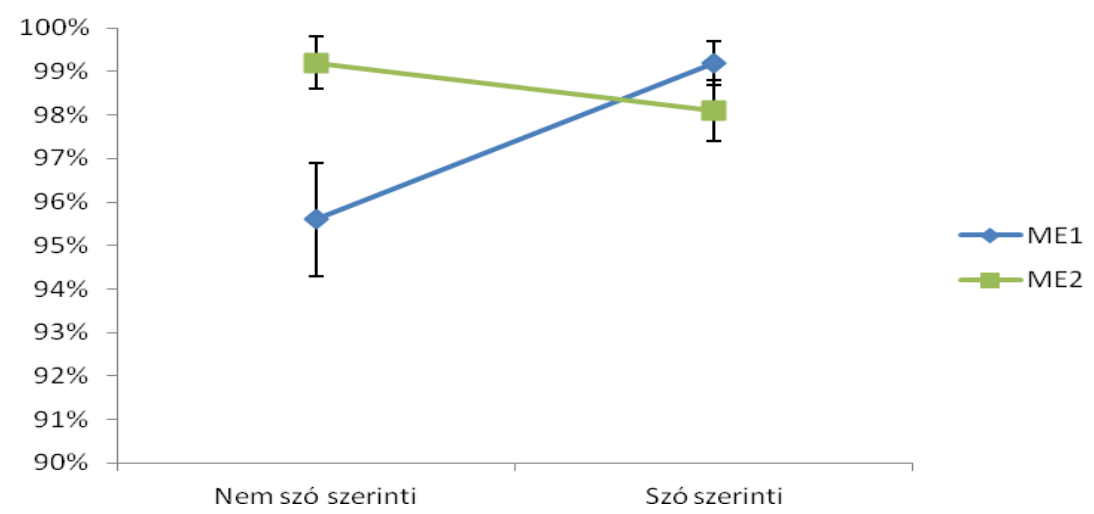

3. ábra. A pontossági adatok alakulása a metafora típusa és a jelentés kapcsolatának tükrében (ME1: konvencionális metafora, ME2: újszerű metafora) 


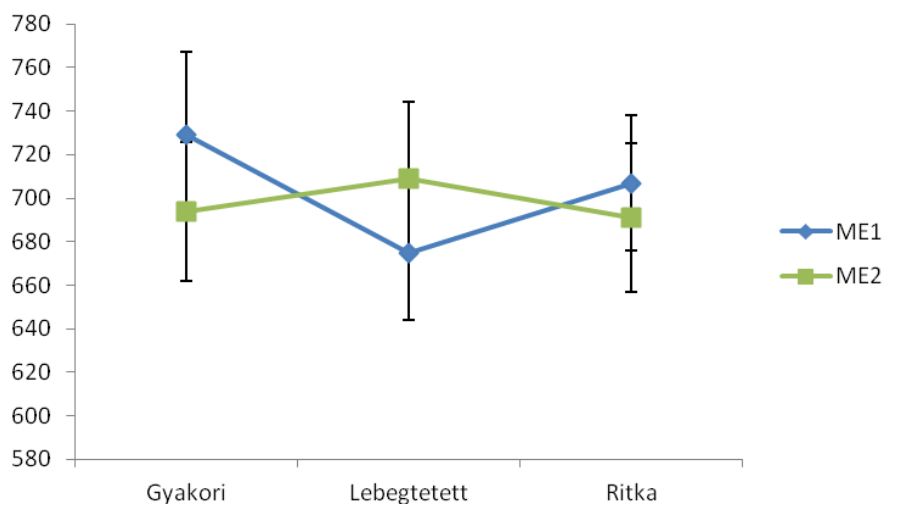

4. ábra. A reakcióidő alakulása a metafora típusa és a kontextus kapcsolatának fényében

A reakcióidő tekintetében a következő szignifikáns eredményeket kaptuk. A 4.ábrából látható, hogy a $\mathrm{ME} \times$ kontextus interakció szignifikáns $(\mathrm{F}(2,38)=4,153$, $p<0,023)$, azaz a kontextusnak és a metafora típusának van szerepe a döntésben. A konvencionális metaforáról való döntés lassabb lett a gyakori kontextusban, mint a ritka vagy lebegtetett kontextusban. A konvencionális metafora lebegtetett kontextusban volt a leggyorsabb (675 msec, $\mathrm{SE}=31)$, ezzel szemben az újszerü metafora a lebegtetett kondícióban volt a leglassabb (709 msec, $\mathrm{SE}=35)$. Az újszerủ metafora gyakori és ritka kontextusban ugyanolyan sebességủ volt (694 és $691 \mathrm{msec}, \mathrm{SE}=32$ és 34; a konvencionális metaforák esetében a gyakori és a ritka kontextusnál az átlagos reakcióidő 729 és $707 \mathrm{msec}, \mathrm{SE}=38$ és 31) (4. ábra). Öszszességében gyakori kontextusban az újszerű metaforáról gyorsabban tudtak döntést hozni, mint a konvencionálisról (690 msec vs. 730 msec).

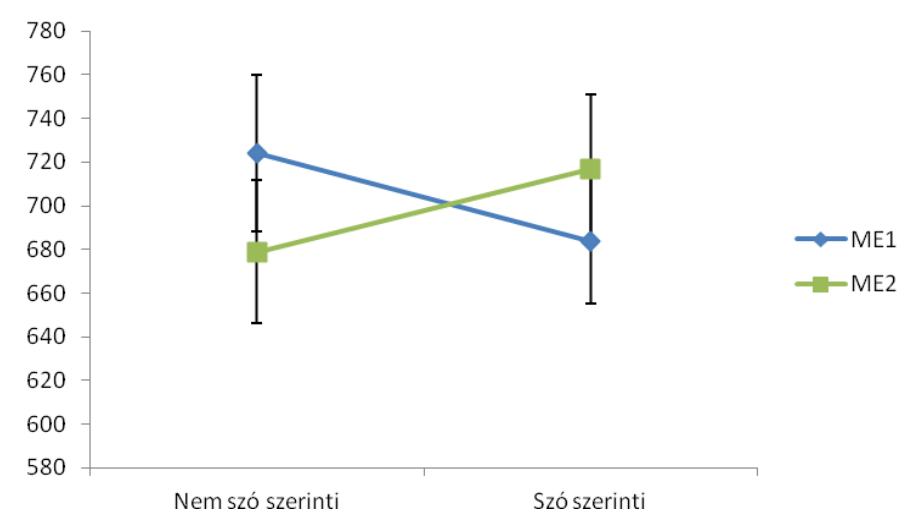

5. ábra. A reakcióidő alakulása a metafora típusa és a jelentések közti kapcsolat fényében 
Szignifikáns ME $\times$ jelentés interakciót kaptunk $\mathrm{F}(1,19)=11,737, p<0,01$ (5. ábra). Ez azt jelenti, hogy a célinger típusának, azaz annak, hogy milyen jelentés kapcsolódott a metaforához, szignifikáns hatása van. A konvencionális metaforához tartozó nem szó szerinti jelentésről lassabban döntöttek, mint a szó szerinti jelentésről, míg az újszerű metaforához tartozó szó szerinti jelentésről lassabban döntöttek, mint a nem szó szerintiről.

\section{A fiatal felnött csoport eredményei}

A pontossági adatait és a reakcióidő-mérés adatait három szempontú, 2 (metafora típusa: konvencionális, újszerű) $\times 3$ (kontextus: gyakori, lebegtetett, ritka) $\times 3$ (jelentés: nem szó szerinti, szó szerinti, nem kapcsolódó) összetartozó mintás ANOVA segítségével elemeztük. Illeszkedés szempontjából eredményeink a jelentés $\times \mathrm{ME}$ (metafora típusa) közti szignifikáns interakciót mutatják $(p<0,005)$.

A reakcióidő-mérés adatainak elemzése során a kamasz korcsoport eredményeitől eltérő eredményeket kaptunk. Szignifikáns kontextus főhatást kaptunk $(\mathrm{F}(2,36)=8,497, p<0,001)$, azaz a gyakori és a ritka kontextusban lévő metaforát egymáshoz képest ugyanolyan sebességgel, a lebegtetett kontextushoz képest pedig gyorsabban hívták elő ( $807 \mathrm{msec}, 833 \mathrm{msec}, \mathrm{SE}=69$ és 79), mint a lebegtetett kontextusban lévőt $(897 \mathrm{msec}, \mathrm{SE}=92)$ (6. ábra). A kamasz korosztállyal ellentétben kaptunk szignifikáns jelentéshatást is $(\mathrm{F}(2,36)=21,737, \mathrm{p}<0,001)$, azaz összességében a szöveghez nem kapcsolódó jelentést lassabban (1005 msec, SE = 106) értették meg, mint a nem szó szerintit (762 msec, $\mathrm{SE}=69$ ) és a szó szerintit (770 msec, $\mathrm{SE}=68)$, amelyeket azonban csaknem egyszerre hívtak elő.

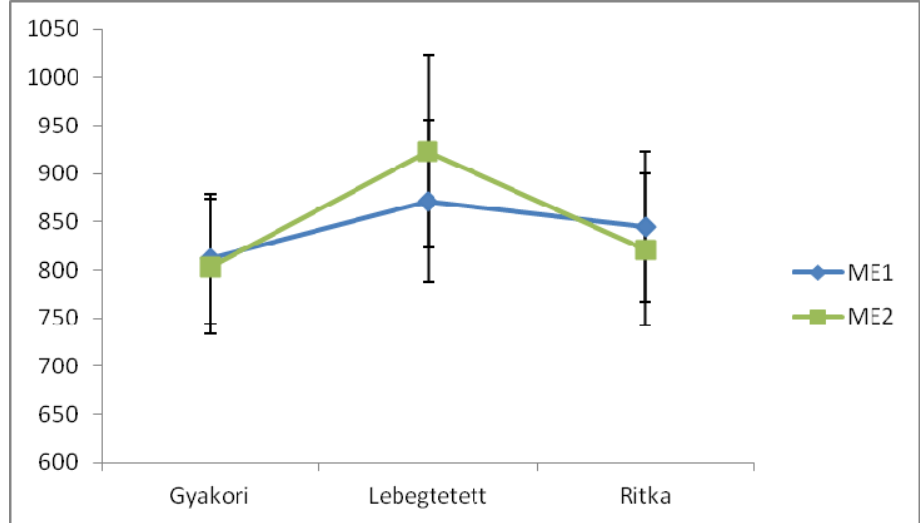

6. ábra. A reakcióidő alakulása a metafora típusa és a kontextus viszonyának fényében 


\section{ÖSSZEGZÉS}

Reakcióidő-méréssel végzett lexikális döntési feladatunk eredményei jól tükrözik a különböző korosztályok által preferált jelentések dominanciaviszonyát. Nézzük most eredményeinket hipotéziseink tükrében.

Első számú hipotézisünk szerint a fiatal felnőtt korosztály a konvencionális metaforák metaforikus jelentését részesíti előnyben, hiszen azok száliens jelentéstartalommal és nagy gyakorisággal rendelkeznek a mindennapi nyelvhasználatban. A metafora típusa és a jelentés szignifikáns interakciója viszont azt mutatja, hogy a konvencionális metaforák nem szó szerinti jelentésének megértése ugyanolyan gyors, mint az újszerű metaforák nem szó szerinti jelentésének feldolgozása, ugyanakkor lebegtetett kontextusban a konvencionális metafora gyorsabb. A metafora típusa és a kontextus közti interakció alapján azt mondhatjuk, hogy a konvencionális és az újszerű metafora megértése közt nincs olyan nagymértékű különbség, mint amilyet a serdülők esetében látunk. Valószínűsíthető az is, hogy a felnőttek a kontextussal inkompatibilis, rögzült konvencionális jelentést kontextustól függetlenül minden alkalommal előhívják, ezért volt lehetséges, hogy nem találtunk reakcióidő-különbséget a szó szerinti és a nem szó szerinti jelentések feldolgozása között. Ez megerősítheti azokat a kutatási eredményeket, amelyek a releváns és irreleváns jelentés kezdeti aktiválódására szolgáltattak bizonyítékokat (például RuBio, 2007, 2008; SwAAB és mtsai, 2003; TURi és mtsai, 2010).

Második hipotézisünk, miszerint a fiatal felnőtt korosztály a konvencionális metaforák esetében a száliens jelentést hívja elő tekintet nélkül a kontextusra, csak részben igazolódott be. A gyakori és a ritka kontextusban mindkét jelentés aktív lehetett, viszont a lebegtetett kontextusban, ahol a választás az adatközlők preferenciájára volt bízva, a konvencionális metafora feldolgozása igényelt kevesebb erőfeszítést. Az újszerủ metafora szignifikánsan megnövekedett feldolgozási ideje a mindkét értelmezést lehetővé tevő kontextusban arra bizonyíték, hogy az ismeretlen és ritka, nem konvencionális jelentést nehezebben dolgozzák fel nem egyértelmű kontextusban.

Harmadik hipotézisünket részben szintén cáfoltuk, mert a fiatal felnőtt korosztály esetében az újszerű metaforák feldolgozási ideje nem különbözött a konvencionális metaforákétól. A kamaszok ezzel szemben az újszerủ metaforák metaforikus jelentésének megtalálásában jobban, míg a konvencionális metafora megértésében kevésbé jól teljesítenek, annak ellenére, hogy azok a gyakoribbak a hétköznapi nyelvhasználatban. A serdülő korosztálynál kapott szignifikáns interakció szerint a konvencionális metaforáról való döntés lassabb a gyakori kontextusban (nem szó szerinti jelentést előfeszítő kontextus), míg az újszerű metaforáról való döntés gyorsabb. A konvencionális metafora lebegtetett kontextusban volt a leggyorsabb ( 675 msec, $\mathrm{SE}=31$ ), ezzel szemben az újszerủ metafora a lebegtetett kondícióban volt a leglassabb (709 msec, $\mathrm{SE}=35)$. Ez az ellentétes mozgás a lebegtetett kontextusban, ahol a választás a leginkább az adatközlő egyéni döntésére volt bízva, azt jelentheti, hogy a konvencionális metaforát az újszerűnél magabiztosabban tudta értelmezni a kamasz korosztály, olyan kontextusban, ahol nemcsak a metafora szokatlanságával kellett megküzdeniük, hanem a szövegkörnyezet kétféle 
értelmezést lehetővé tevő jellegével. A kezdeti aktiváció során tehát az a jelentés marad aktív a lebegtetett kontextusban, amely relevánsabb lehet az interpretálás során. A serdülő korosztály számára (és a felnőtt korosztály számára is) a konvencionális metafora metaforikus jelentése a „biztosabb választás”.

Míg a fiatal felnőtt korosztály számára a konvencionális metaforák metaforikus jelentése ugyanolyan sebességgel hívódott elő, mint az újszerủ metaforák metaforikus jelentése, a kamasz korcsoport a konvencionális metaforák metaforikus jelentését lassabban értette meg, bármennyire is gyakran használt és ismerős volt a metafora, mint az újszerű metaforákét

Ez összhangban van a Kognitív Kongruencia Hipotézisével (SCHNELL, 2012), ezzel összefüggésben lényeges faktor a kontextus és a pragmatika egyértelműsítő hatása. Forgács kiemeli a relevanciaelmélet azon állítását, hogy a „szavak jelentését rendszeresen tágítjuk és szűkítjük. [...] A metaforák a jelentés tág végletéhez esnek közel, ezért nem alkotnak önálló nyelvi kategóriát. [...] A jelek és a jelentések szorosan nem feleltethetők meg egymásnak, kizárólag a kontextus egyértelműsít. Mindazonáltal a jelentés rugalmas tágítása, „eltolása” a metaforák legfontosabb tulajdonsága. [...] Habár a jelölők grice-i értelemben valóban nem feleltethetők meg maradéktalanul a szó szerinti jelölteknek, a használati gyakoriságok mégis a lehetséges jelentések bizonyos véges tartományát rendelik egy-egy szó köré. Ezek közül válogathatunk és választhatjuk ki a legrelevánsabbat, az aktuális kommunikációs céloknak megfelelően" (FORGÁCS, 2014, 401-402). Így az absztrakt fogalmak iránti fogékonyság egy lehetséges magyarázatként szolgálhat az eredményeinkre.

Úgy tűnik, serdülőkorban léteznek kevésbé preferált jelentések, amelyek csak erős kontextuális hozzájárulás segítségével érthetők meg, illetve léteznek olyan egyedi, kreatív nyelvi alakzatok, amelyek rögtön hozzáférhetők a korosztály számára, sőt a korcsoport számára nem igényelt nagyobb erőfeszítést, viszont garantálja a maximális hatást. A nem preferált, konvencionális metaforák megértése ennél jóval nagyobb erőfeszítést igényelt, így az mondható, hogy a kamasz korosztály összetettebb és kreatívabb mentális múveletekre képes az ismeretlen, játékosságot igénylő kifejezések feldolgozásában.

Végül, negyedik hipotézisünket, miszerint az álszavak reakcióideje lassabb és pontatlanabb lesz, teljes mértékben igazoltuk. A szignifikáns metafora típusa és a jelentés közti interakció azt jelzi, hogy a szöveghez nem kapcsolódó, azaz nem létező magyar szavak reakcióideje jóval magasabb volt, mint a metafora konvencionális vagy nem konvencionális jelentéséé. Ebből az is látszik, hogy az álszavak esetében nem lehet szemantikai előfeszítésről beszélni.

Összességében elmondhatjuk, hogy a konvencionális metaforák megértésének folyamata az életkor előrehaladtával fokozatosan változik, azaz az életkor növekedésével egyre inkább a gyakran használt, metaforikus jelentés lesz a preferált, míg úgy tűnik, a fiatal korosztály érzékenyebb a nyelvi újdonságokra, így az újszerủ metaforák megértése nekik okoz kevesebb nehézséget. A serdülők ilyen típusú következetési képességei miatt gyorsabban és sikeresebben képesek reagálni egy olyan szituációban, ahol egy újonnan hallott/olvasott alakzatnak kell megtalálni a metaforikus jelentését, mint a felnőtt korosztály, akik kevesebb energiát fordíta- 
nak megértésükre. Eredményeink alapján a 15-18 korosztály tűnik a kreatívabb nyelvhasználónak, szemben a felnőtt korosztállyal.

\section{IRODALOM}

Baron-Cohen, S., Leslie, A. M., \& Frith, U. (1985). Does the autistic child have a "theory of mind"? Cognition, 21(1), 37-46.

Baron-Cohen, S., Tager-Flusberg, H., \& Cohen, D. J. (1993). Understanding Other Minds: Perspectives from Autism. Oxford: Oxford University Press.

Baron-Cohen, S., Tager-Flusberg, H., \& Cohen, D. J. (2007). Understanding Other Minds: Perspectives from Developmental Cognitive Neuroscience. $2^{\text {nd }}$ edition. Oxford: Oxford University Press.

Bernicot, J., Laval, V., \& Chaminaud, S. (2007). Nonliteral language forms in children: In what order are they acquired in pragmatics and metapragmatics? Journal of Pragmatics, 39, 2115-2132.

Blakemore S.-J. (2012b). Imaging brain development: The adolescent brain. Neuroimage, $61,397-406$.

Blakemore, S. J., den Ouden, H., Choudhury, S., \& Frith, C. (2007). Adolescent development of the neural circuitry for thinking about intentions. Social Cognitive and Affective Neuroscience, 2(2), 130-139.

Blakemore, S.-J. (2012a). Development of the social brain in adolescence. Journal of the Royal Society of Medicine, 105, 111-116.

Burnett, S., Thompson, S. S., Bird, G., \& Blakemore, S. J. (2011). Pubertal development of the understanding of social emotions: Implications for education. Journal of Learning and Individual Differences, 21, 681-689.

Call, J., \& Tomasello, M. (2008). Do chimpanzees have a theory of mind: 30 years later. Trends in Cognitive Science, 12, 187-192.

Carston, R. (2002). Thoughts and Utterances: The Pragmatics of Explicit Communication. Oxford: Blackwell.

Carston, R. (2010). Metaphor: ad hoc concepts, literal meaning and mental images. Proceedings of the Aristotelian Society, 110(3), 295-321.

Csibra G., Gergely Gy. (2005). Teleologikus gondolkodás csecsemőkorban. Az egyévesek naiv racionális cselekvéselmélete. Magyar Tudomány, 11, 1347-1355.

Erikson, E. H. (1968). Identity: Youth and Crisis. New York: W. W. Norton.

Forgács, B., Bohrn, I., Baudewig, J., Hofmann, M. J., Pléh, Cs., \& Jacobs, A. M. (2012). Neural correlates of combinatorial semantic processing of literal and figurative noun noun compound words. Neuroimage, 63(3), 1432-1442.

FORGÁCS, B. (2009). Verbális metakommunikáció - Mitől releváns egy metaforikus leképezés? Magyar Pszichológiai Szemle, 64(3), 593-605.

Forgács, B., LukÁCS, A., \& PléH, Cs. (2014). Lateralized processing of novel metaphors: Disentangling figurativeness and novelty neuropsychologia. Neuropsychologia, 56, 101109. 
FORGÁCS B. (2013). Agy és megismerés a figuratív nyelv megértésében. In PléH Cs. (szerk.), Általános Nyelvészeti Tanulmányok XXV. A kognitív szempont a nyelv pszichológiááában (383-411). Budapest: Akadémiai Kiadó.

GERőCs M. és PINTÉr L. (2013). A gyerekek mindig pontosan értik a számneveket? Konferenciaelőadás. Szeged: LingDok.

GIBBS, R. (2002). A new look at literal meaning in understanding what is said and implicated. Journal of Pragmatics, 34, 457-486.

Gibbs, R., \& Colston, H. L. (2012). Interpreting Figurative Meaning. Cambridge: Cambridge University Press.

GIORA, R. (1997). Understanding figurative and literal language: The graded salience hypothesis. Cognitive Linguistics, 8(3), 183-206.

GIORA, R. (2002). Literal vs. figurative language: Different or equal? Journal of Pragmatics, 34, 487-506.

GIORA, R. (2007). Is Metaphor Special? Brain and Language, 100, 111-114.

GIORA, R. (2008). Is metaphor unique? In R. Gibbs (Ed.), The Cambridge Handbook of Metaphor and Thought (143-161). New York: Cambridge University Press.

GIORA, R. (2012). The psychology of utterance processing: Context vs. salience. In K. I. Jaszczolt, \& K. Allan (Eds.), The Cambridge Handbook of Pragmatics (151-167). Cambridge: Cambridge University Press.

GlucksberG, S. (2003). The psycholinguistics of metaphor. TRENDS in Cognitive Sciences, 7(2), 92-96.

Grice, H. P. (1997a). A társalgás logikája. In PléH Cs., Síklaki I., Terestyéni T. (szerk.), Nyelv-kommunikáció-cselekvés (188-197). Budapest: Osiris.

Grice, H. P. (1997b). A társalgás logikája. In PléH Cs., Síklaki I., Terestyéni T. (szerk.), Nyelv-kommunikáció-cselekvés (213-227). Budapest: Osiris.

GYŐRI M., GY. STEFANIK K., KANIZSAI N. I. és BALÁZS A. (2002). Naiv tudatelmélet és nyelvi pragmatika magasan funkcionáló autizmusban: reprezentációs zavar, performanciakorlát vagy kompenzáció? In RACSMÁNy M. és KéRI Sz. (szerk.), Architektúra és patológia a megismerésben. Kognitív Szeminárium (11-40). Budapest: Books in Print.

GYŐRI, M. (2006). Autism and Cognitive Architecture. Budapest: Akadémiai Kiadó.

HAppé, F. (1993). Communicative competence and theory of mind in autism: A test of relevance theory. Cognition, 48, 101-119.

Inhelder, B., \& Piaget, J. (1958). The Growth of Logical Thinking from Childhood to Adolescence. New York, NY: Basic Books.

IVASKÓ L. (2004). A pragmatikai kompetencia: nyelvelméleti érvek és neurolingvisztikai realitás. In IVASKÓ L. (szerk.), A kommunikáció útjai (181-196). Budapest: Gondolat/ MTA-ELTE Kommunikációelméleti Kutatócsoport.

KeAting, D. (1980). Thinking processes in adolescence. In J. Adelson (Ed.), Handbook of adolescent psychology (211-246). New York: Wiley.

LACZKó M. (2008). Hogyan minősítik tizenévesek beszédét a diákok, és hogyan a tanárok? Anyanyelv-Pedagógia, 1(3-4), 87.

LACZKó M. (2009). Tizenévesek beszédének fonetikai-stilisztikai elemzése. AnyanyelvPedagógia, 2(1-2), 151

LACZKó M. (2011). Óvodások és kisiskolások spontán beszédalkotási folyamatai. Magyar nyelvör, 135, 440-459. 
LAVAL, V., \& Bernicot, J. (2002). Tu es dans la lune: Understanding idioms in French speaking children and adults. Pragmatics, 12(4), 399-413.

LENGYel, Zs., BALÁZs, P., \& IVASKÓ, L. (2011). Intended or not intended, literal or nonliteral meaning - some evidence from normally developing Hungarian children. $12^{\text {th }}$ International Pragmatics Conference, Manchester, England, 2011. július 3-8.

Loukusa, S., Leinonen, E., \& Ryder, N. (2007/08). Development of pragmatic language comprehension in Finnish-speaking children, First Language, 27(3), 279-296.

LukÁCS Á., PléH Cs. (2003). A nyelv idegrendszeri reprezentációja. In PléH Cs., KovÁCS Gy. és GulYÁs B. (szerk.), Kognitív idegtudomány (528-561). Budapest: Osiris.

Nemesi A. L. (2009). Az alakzatok kérdése a pragmatikában. Budapest: Loisir.

Racsmány M., Lukács Á., Németh D. és PléH, Cs. (2005). A verbális munkamemória magyar nyelvű vizsgálóeljárásai. Magyar Pszichológiai Szemle, 60(4), 479-506.

Rubio, F. P. (2007). Suppression in metaphor interpretation: Differences between meaning selection and meaning construction. Journal of Semantics (Special Issue on Processing Meaning), 24(4), 345-371.

Rubio, F. P. (2008). Concept narrowing: The role of context-independent information in concepts. Journal of Semantics, 25(4), 381-409.

SCHNELl Zs. (2007). Tudatelmélet és pragmatika-idiomatikus nyelvelsajátítás. In MUND K. és KAMPIS Gy. (szerk.), Tudat és elme (145-168). Budapest: Typotex.

SCHNELL Zs. (2013). A gyermekhumor kognitív nyelvészeti vizsgálata. In VARGHA, K., LITOVkina, A. és BARTA Zs. (szerk.), Sokszínü humor. A III. Magyar Interdiszciplináris konferencia előadásai (195-212). Budapest: Tinta Kiadó/ELTE BTK Magyar Szemiotikai Társaság.

Schnell, Zs., \& VARGA, E. (2012). Humour, Irony and Social Cognition. In A. T. LItovkinA, J. SzŐllősy, P. Medgyes, \& W. ChŁoPicki (Eds.), Hungarian Humour. Humor and Culture 3. Cracow: Tertium Society for the Promotion of Language Studies.

SEARle, J. R. (1979). Metaphor. Expression and Meaning: Studies in the Theory of Speech Acts. Cambridge: Cambridge University Press.

Sperber, D., \& Wilson, D. (1995). Relevance: Communication and Cognition. $2^{\text {nd }}$ edition. Oxford: Blackwell.

Sperber, D. és Wilson, D. (2013). A metafora leleplezése megértésében. In PléH Cs. (szerk.), Általános Nyelvészeti Tanulmányok XXV. A kognitív szempont a nyelv pszichológiájában (313-339). Budapest: Akadémiai Kiadó.

SwaAb, T., Brown, C. M., \& Hagoort, P. (2003). Understanding words in sentence contexts: The time course of ambiguity resolution. Brain and Language, 86(2), 326-343.

Tomasello, M. (2002). Gondolkodás és kultúra. Budapest: Osiris.

TURi Zs., Janacsek K. és NÉmeth D. (2010). A munkamemória, a szógyakoriság és a kontextus szerepe a lexikális kétértelműség feldolgozásában. Pszichológia, 30(4), 295-315.

Werner, H., \& Kaplan, B. (1952). The Acquisition of Word Meanings: A Developmental Study. Monographs of the Society for Research in Child Development, 15/1. Washington: Society for Research in Child Development. 


\title{
UNDERSTANDING CONVENTIONAL AND NOVEL METAPHORS BY TEENAGERS AND YOUNG ADULTS
}

\author{
BALÁZS, PATRÍCIA - KEMÉNY, FERENC - IVASKÓ, LÍVIA
}

\begin{abstract}
Apart from cognitive and experimental psychology (see also TURI et al., 2010; SWAAB et al., 2003), experimental pragmatics also deals with the comprehension of non-literal meanings (GIORA, 2002, 2007, 2008, 2012; GIBBS, 2002). The different ways of how metaphors are processed, which is a particularly interesting topic, leads to new results when analysed in various age groups and in the case of subjects with different cognitive abilities (LOUKUSA, LEINONEN, \& RYDER, 2007/08; SCHNELL, 2007). The language use and comprehension of adolescents, young people between 15 and 18 years of age, have not been widely studied so far. The present study investigates how conventional and new (creative) metaphors are comprehended by teenagers and young adults by means of word/non-word lexical decision tasks. Metaphors are embedded into three different contexts: 1. contexts which facilitate the comprehension of the (more) salient meaning of metaphors, 2. contexts which facilitate the comprehension of the (less) salient meaning of metaphors, and 3. the so-called "floating" contexts (ones which might facilitate the comprehension of either the more salient or the less salient meanings of metaphors). The target words embedded into the test included either metaphors used in their conventional or nonconventional meanings. Furthermore, additional pseudowords were also used in the experiment, functioning as control words. Our findings reveal that adolescents tend to pay significant attention to those words they have not heard before (new and rarely-heard ones). What is more, they tend to comprehend these words in their metaphorical meaning faster than the aforementioned conventional metaphors. However, with the advancement of age, their comprehension of conventional forms is gradually better.
\end{abstract}

Key words: adolescents, conventional and new metaphors, experimental pragmatics, lexical decision task, metaphorical meaning 